\title{
Rapid NPK diagnosis in tomato using petiole sap analysis with the DRIS method
}

\author{
Luciano Ávila-Juárez 1D; Mario A Rodríguez-Ruiz ${ }^{1 \mathbb{D}}$
}

${ }^{1}$ Biosystems Engineering Group, Division of Graduate Studies, School of Engineering, Universidad Autónoma de Querétaro, Santiago de Querétaro, Querétaro, México; luciano.avila@uaq.mx (autor for correspondence); alexx-fi@hotmail.com

\begin{abstract}
One of the factors determining success in tomato production is plant nutrition. The diagnosis and recommendation integrated system (DRIS) is a tool used to obtain fertilizer recommendations. The objective of this study was to determine DRIS indices using petiole sap analysis (PSA) and compare them with those obtained using leaf analysis in two tomato cultivars grown under greenhouse conditions. A complete randomized design with eight treatments and 60 plants per experimental unit was used. To determine whether employing PSA with the DRIS methodology can provide a reliable diagnosis of fertilization, doses of some elements, such as N, P, or $\mathrm{K}$, were reduced by $30 \%$ and supplied to two tomato cultivars, namely, Cid and Moctezuma. The indices for PSA-DRIS and DRIS were estimated. $\mathrm{R}^{2}$ values greater than 0.84 were obtained for the relationships between the leaf concentrations and petiole extract $(\mathrm{PE})$ concentrations of some elements in both tomato cultivars. The PSADRIS method detected $62.5 \%$ of the cases of deficiency identified via DRIS. The PSA-DRIS method is a low-cost way to rapidly fertilize recommendations in tomato.
\end{abstract}

Keywords: Solanum lycopersicum, petiole extract, nutritional balance, nutrients.

\section{RESUMO}

Diagnóstico rápido de NPK em tomate por meio da análise da seiva de pecíolos e pelo método DRIS

Um dos fatores que determina o sucesso na produção de tomate é a nutrição das plantas. O sistema integrado de diagnóstico e recomendação (DRIS) é uma ferramenta usada para obter recomendações de fertilizantes. O objetivo deste estudo foi determinar os índices DRIS usando análise de seiva de pecíolo (PSA) e comparálos com os obtidos pela análise foliar em duas cultivares de tomate cultivadas em casa de vegetação. $\mathrm{O}$ delineamento experimental foi inteiramente casualizado, com oito tratamentos e 60 plantas por unidade experimental. Para determinar se o emprego de PSA com a metodologia DRIS pode fornecer um diagnóstico confiável de fertilização, as doses de alguns elementos, como N, P ou K, foram reduzidas em $30 \%$ e fornecidas a duas cultivares de tomate, Cid e Moctezuma. Os índices para PSA-DRIS e DRIS foram estimados. Valores de $\mathrm{R}^{2}$ superiores a 0,84 foram obtidos para as relações entre as concentrações foliares e extrato de pecíolo (PE) de alguns elementos em ambas as cultivares de tomate. O método PSA-DRIS detectou $62,5 \%$ dos casos de deficiência identificados via DRIS. O método PSA-DRIS é uma maneira de baixo custo para recomendação rápida de fertilização do tomate.

Palavras-chave: Solanum lycopersicum, extrato do pecíolo, balanço nutricional, nutrientes.

\section{Received on November 28, 2019; accepted on June 30, 2020}

$\mathrm{T}^{\mathrm{s}}$ he efficient use of fertilizers in tomato crops is important not only to reduce production costs but also to minimize possible negative effects on the environment (Hochmuth et al., 2004). Foliar analysis is considered very practical for the diagnosis of nutritional disorders (Dezordi et al., 2016) and is superior to soil analysis for determining the nutritional status of a crop as soil analysis only determines the nutrients immediately available in the soil (Shunfeng et al., 2018). However, foliar analysis has the disadvantages of being expensive and requiring several days to conduct. In addition, the levels of leaf nutrients are influenced by concentration effects due to limiting factors in development and dilution effects due to culture medium conditions (Cadahía, 2008).

As an alternative, sap analysis, also known as petiole sap analysis (PSA), is a quick and effective tool for determining the nutritional status of a crop. This method is based on the measurement of the concentrations of nutrients in the leaf petiole sap (Bityutski et al.,
2017). In PSA, before sap extraction, the petioles should be sampled in the field, managed and stored following standard protocols (Araya et al., 2015), then analyzed immediately to avoid changes in nutrient contents (Thompson et al., 2009). According to Cadahía (2008), sap concentrations are less affected by concentration and dilution effects than are foliar concentrations; thus, sap analysis offers a diagnosis that not only is more accurate than that offered by foliar analysis but also requires less time. Several types of 
equipment are available for measuring the concentrations of ions in plant sap, such as colorimeters and specific ion electrodes (Hochmuth et al., 2004), that yield values with strong correlations $\left(r^{2}=0.96, p<0.0001\right)$ with those obtained from conventional laboratory analyses (Tully \& Weil, 2014). This equipment has been used successfully in various crops, such as tomato (Hochmuth et al., 2004; Farneselli et al., 2014) and leafy vegetables such as lettuce, spinach, and Asian vegetables (Ott-Borrelli et al., 2009; Parks et al., 2012). However, it is difficult to interpret the results of sap analysis of crops, in particular, it is difficult to determine whether a nutrient is present in excess or is deficient and thus negatively affecting yield.

One of the best methods for the interpretation of foliar analysis results is the diagnosis and recommendation integrated system (DRIS) (Beaufils, 1973; Walworth \& Sumner, 1987). The DRIS evaluates the nutritional status of a plant by comparing the relative proportions of nutrient pairs in the foliar tissue with published standards for the crop (Soltanpour et al., 1995). The results are expressed as indices representing, on a numerical scale, the effects of individual nutrients on the nutritional balance of the plant (Bhaduri \& Pal, 2013).

Considering that DRIS uses the concept of nutritional balance and is suitable for the detection of deficiencies and/or nutritional excesses (Bhaduri \& Pal, 2013) and that sap analysis is a very useful and rapid method for the detection of xylem and phloem concentrations of nutrients in a cultivar (Farneselli et al., 2014), the objective of this study was to compare the DRIS indices obtained based on foliar analysis with those obtained based on PSA in two tomato cultivars.

\section{MATERIAL AND METHODS}

The experiment was conducted from March to December 2018 at the Universidad Autónoma de Querétaro, Mexico (20¹1'17'N, 10008'38' W, altitude $2629 \mathrm{~m}$ ). The tomato (Solanum lycopersicum) cultivars used were Cid and Moctezuma from the Harris Moran
Company (USA) and were grown under greenhouse conditions.

The tomato plants were grown hydroponically in blocks of rock wool $(1 \times 0.2 \times 0.075 \mathrm{~m})$ at a density of 2.5 plants $\mathrm{m}^{-2}(0.4 \mathrm{~m}$ separation between each block of rock wool, $1.6 \mathrm{~m}$ between furrows). The nutrient solution used was Steiner solution (Steiner, 1984) with a $\mathrm{pH}$ of 5.8 containing the following in mg L-1: N, 167; P, 31; K, 277; Mg, 49; Ca, 183; S, 111; Fe, 1.33; Mn, 0.62; B, 0.44; Cu, 0.02; Zn, 0.11; and Mo, 0.048. The nutrient solution was applied into two stages according to Ávila-Juárez et al. (2015). The temperature, relative humidity, and total solar radiation were $30.5 / 10.5^{\circ} \mathrm{C}$ (day/night), 60.4/33.7\% (day/night), and $955 \mathrm{~W} \mathrm{~m}^{-2}$ (maximum), respectively, during the experiment.

To achieve known nutritional deficiencies for the treatments, $\mathrm{N}$, $\mathrm{P}$, or $\mathrm{K}$ was reduced by $30 \%$ in the nutrient solution. Two cultivars (Cid and Moctezuma) were used, yielding a total of eight treatments, including control treatments, in which nutrients were not reduced. Sixty plants comprised each experimental unit. The experimental design was completely randomized. The treatments were coded as T1 (-NCid), T2 (-PCid), T3 (-KCid), T4 (-NMoc), T5 (-PMoc), T6 (-KMoc), T7 (control treatment; controlCid for $\mathrm{N}, \mathrm{P}$, or $\mathrm{K}$ ), and T8 (control treatment; controlMoc for $\mathrm{N}, \mathrm{P}$, or $\mathrm{K}$ ), where $\mathrm{T}=$ treatment, $\mathrm{N}=$ nitrogen, $\mathrm{P}=$ phosphorus, $\mathrm{K}=$ potassium, Moc $=$ Moctezuma cultivar, and $\mathrm{Cid}=$ Cid cultivar.

For the extraction of petiole sap, the fifth developed young leaf $(n=60)$ from the top of the plant was collected (9:00 am). Petiole extract (PE) sampling and foliar analyses were performed when the plant presented cluster number five (120 days after transplant). Subsequently, for the analysis of PE, the leaflets were removed from the leaf, leaving only the petioles, which were cut to $0.5 \mathrm{~cm}$ in length and frozen for $24 \mathrm{~h}$. The PE was extracted with a hydraulic press and diluted to a ratio of one part PE to 90 parts deionized water. The dilution was prepared according to the equipment specifications and immediately analyzed by a colorimeter model HI83225 (Hanna Instruments, USA). $\mathrm{N}\left(\mathrm{NO}_{3}-\mathrm{N}\right)$ was determined by the cadmium reduction method, $\mathrm{P}\left(\mathrm{PO}_{4}-\mathrm{P}\right)$ was determined by the amino acid method, and $\mathrm{K}$ was determined by the tetraphenylborate turbidimetric method.

For foliar analysis, leaves $(n=60)$ were collected from different parts of the plant and then immediately analyzed in a certified laboratory (Laboratorio de Nutrición Vegetal SC) in Guanajuato, Mexico. N was determined according to the Kjeldahl method, and $\mathrm{K}$ was determined by atomic absorption followed by wet digestion. P was determined by spectrophotometry after digestion and calcination according to Ávila-Juárez et al. (2015).

To determine the deficiency induced by each treatment presented as a percentage, the result for each element $(\mathrm{N}, \mathrm{P}$ or $\mathrm{K})$ in leaf or PE was multiplied by 100 and then divided by the control value (without deficiency); then, 100 was subtracted. This procedure was performed to compare the laboratory results with the PSA results.

The DRIS standards for greenhouse tomato were provided by the Mexican National Institute of Forestry, Agriculture and Livestock Research (Instituto Nacional de Investigaciones Forestales, Agrícolas y Pecuarias - INIFAP) and were $\mathrm{N} / \mathrm{P}=8.947$, coefficient of variation $(\mathrm{CV})=30 ; \mathrm{N} / \mathrm{K}=1.063, \mathrm{CV}=20$; and $\mathrm{P} /$ $\mathrm{K}=0.119, \mathrm{CV}=25$.

The DRIS and PSA-DRIS indices were calculated for each treatment in two steps. First, for each pair of nutrients, the observations were related to the existing norms by calculating the standardization index according to Beaufils (1973) as follows:

$$
\begin{gathered}
f(N / P)=\left(\frac{N / P}{n / p}-1\right)\left(\frac{1000}{C V_{n / p}}\right) \\
\text { if } N / P>n / p \\
f(N / P)=\left(1-\frac{n / p}{N / P}\right)\left(\frac{1000}{C V_{n / p}}\right) \\
\text { if } N / P<n / p
\end{gathered}
$$

where the lowercase letters refer to the nutrient ratios of the published standards, uppercase letters refer to the samples of the foliar analysis or PSA, $\mathrm{f}$ is the function of the sample, and $\mathrm{CV}$ is the coefficient of variation associated with the standard. Once the 
functions were calculated, we calculated the indices for each element as follows (Walworth \& Summer 1987):

$A=\frac{ \pm f(A / B) \pm f(A / C) \pm f(A / D) \ldots \pm f(A / N)}{Z}$

where $\mathrm{f}(\mathrm{A} / \mathrm{B})$ is the ratio function of nutrients $\mathrm{A}$ and $\mathrm{B}$. The symbol \pm indicates the following: if $A$ is the numerator in the function $\mathrm{f}(\mathrm{A} / \mathrm{B})$, addition is performed; otherwise, subtraction is performed (Píperas et al., 2009); the same approach applies to the remaining nutrient ratios. $\mathrm{Z}$ is the number of functions present in the A index.

\section{RESULTS AND DISCUSSION}

The laboratory analyses revealed a significant difference between each deficiency treatment and the corresponding control (without deficiency) except for $\mathrm{N}$ in the Moctezuma cultivar, confirming the induction of deficiency. To compare the laboratory and PSA approaches, the data were standardized using the percentage deficiency (as described in the material and methods section). Our results confirm that colorimetric analysis is capable of detecting nutrient deviations as traditional analysis can but more quickly (Table 1). In fact, there was no significant difference in the percentage of induced deficiency between the two methodologies. Colorimetry analysis of $\mathrm{NO}_{3}-\mathrm{N}$ has been reported to be a reliable method for measuring $\mathrm{N}$ in PCE (Ott-Borrelli et al., 2009), although it can vary with species and environmental conditions (Goffart et al., 2008). Our results identified no significant differences in percentage deficiency for $\mathrm{N}$ or the other analyzed elements between the PSA method and the laboratory method. These results are significant because they show that equipment such as portable colorimeters can generate values equivalent to those obtained via laboratory analysis (with some uncertainty and high cost of $\$ 31$ USD/sample), allowing a producer to rapidly (in less than $24 \mathrm{~h}$ ) and economically (at less than \$1.5 USD/ sample) obtain information on the nutritional status of a crop.

$P$ is especially important in the initial stages of crop development (Hopkins et al., 2014); it is translocated from lower leaves to areas of new growth (Hochmuth et al., 2004). Because P is a highly mobile element in plants, deficiencies (less than $0.1 \%$ dry weight) are visually perceptible in the oldest leaves (Hochmuth et al., 2004). Values well above $0.1 \%$ weight based on dry matter were obtained in treatments where $\mathrm{P}$ deficiency was induced (T2 and T5), although they were significantly lower than the corresponding control values. The PSA method indicated up to $55 \%$ deficiency of $\mathrm{P}$ relative to the control percentage in the Cid cultivar, and this percentage was statistically equivalent to the percentage $P$ deficiency indicated by the laboratory method. This result suggests that the $\mathrm{P}$ content in tomato plants can very feasibly be quantified via PSA.

The laboratory results revealed a significant difference between the K-deficiency treatment and the control treatment in both cultivars. However, there was no significant difference in the percentage of induced deficiency between the PCE method and the laboratory method. In the Cid cultivar, the laboratory analysis indicated an induced deficiency of $35.18 \%$, whereas the PSA indicated a deficiency of $11.93 \%$. The small amount of $\mathrm{K}$ in the petiole of the tomato leaf might reflect translocation that was too slow or

Table 1. Induced deficiencies and data variation between laboratory analysis (leaf analysis) and petiole sap analysis (PSA) in two tomato cultivars. Querétaro, UAQ, 2018.

\begin{tabular}{|c|c|c|c|c|}
\hline \multirow{2}{*}{ Treatment } & \multicolumn{2}{|c|}{ Laboratory } & \multicolumn{2}{|r|}{ PSA } \\
\hline & Lab $(\%)^{w}$ & Deficiency $^{\mathrm{g}}(\%)$ & PE (ppm) $)^{w}$ & Deficiency $^{\mathrm{g}}(\%)$ \\
\hline -NCid & $3.57 \mathrm{NS}$ & $11.7 \pm 7.8^{\mathrm{a}}$ & 816 & $39.9 \pm 19.8^{\mathrm{a}}$ \\
\hline -NMoc & $3.25 * *$ & $20.0 \pm 4.8^{\mathrm{a}}$ & 600 & $33.6 \pm 8.8^{\mathrm{a}}$ \\
\hline -PCid & $0.30 * *$ & $53.7 \pm 13.5^{\mathrm{a}}$ & 343 & $55.5 \pm 4.9^{\mathrm{a}}$ \\
\hline -PMoc & $0.38^{*}$ & $53.9 \pm 28.0^{\mathrm{a}}$ & 426 & $43.3 \pm 28.6^{\mathrm{a}}$ \\
\hline$-\mathrm{KCid}$ & $2.76^{*}$ & $35.1 \pm 18.1^{\mathrm{a}}$ & 1616 & $11.9 \pm 8.0^{\mathrm{a}}$ \\
\hline -KMoc & $3.18^{*}$ & $20.4 \pm 12.1^{\mathrm{a}}$ & 1700 & $8.8 \pm 5.4^{\mathrm{a}}$ \\
\hline control Cid N & 4.05 & & 1356 & \\
\hline control Moc $\mathrm{N}$ & 4.06 & & 910 & \\
\hline control Cid P & 0.66 & & 776 & \\
\hline control Moc P & 0.83 & & 783 & \\
\hline control Cid K & 4.25 & & 1840 & \\
\hline control Moc K & 4.00 & & 1866 & \\
\hline
\end{tabular}

${ }^{g}$ Deficiency induced relative to the control level (mean \pm standard deviation). ${ }^{\mathrm{w}}$ Comparison of induced deficiency in laboratory analysis vs. the respective control (e.g., -NCid vs. control Cid N); Tukey, $\mathrm{p}<0.05(*)$ and $\mathrm{p}<0.01(* *)$. Moc=cv. Moctezuma; Cid=cv. Cid; $-\mathrm{N}=$ nitrogen deficiency, $-\mathrm{P}=$ phosphorus deficiency, $-\mathrm{K}=$ potassium deficiency. Means within a row with different letters are significantly different, Tukey, $\mathrm{p}<0.05$.

Table 2. Relationships between the concentrations of nutrients in tomato leaf and those in petiole extract (PE) in two tomato cultivars (in treatments without induced deficiency). Querétaro, UAQ, 2018.

\begin{tabular}{lcccc}
\hline \multirow{2}{*}{ Cultivar } & \multicolumn{4}{c}{ Relationship between foliar and PE concentrations } \\
\cline { 2 - 5 } & Element & Slope & Intercept & $\mathbf{R}^{\mathbf{2}}$ \\
\hline \multirow{3}{*}{ Cid } & $\mathrm{A}$ & $4 \times 10^{-4}$ & 3.55 & 0.98 \\
& $\mathrm{P}$ & $-1 \times 10^{-4}$ & 0.77 & 0.97 \\
\multirow{3}{*}{ Moctezuma } & $\mathrm{K}$ & $-5 \times 10^{-7}$ & 4.34 & 0.98 \\
& $\mathrm{~N}$ & $6 \times 10^{-4}$ & 3.54 & 0.99 \\
& $\mathrm{P}$ & $2 \times 10^{-4}$ & 0.67 & 0.99 \\
& $\mathrm{~K}$ & $-5 \times 10^{-9}$ & 4.15 & 0.84 \\
\hline
\end{tabular}


Table 3. Indexes, excesses, and deficiencies as evidenced by DRIS and PSA-DRIS in two tomato cultivars. Querétaro, UAQ, 2018.

\begin{tabular}{|c|c|c|c|c|c|c|c|c|c|c|}
\hline \multirow{2}{*}{ Treatment } & \multicolumn{3}{|c|}{ DRIS } & \multicolumn{3}{|c|}{ PSA-DRIS } & \multicolumn{2}{|c|}{ Deficiency } & \multicolumn{2}{|c|}{ Excess } \\
\hline & $\mathbf{I}_{\mathrm{N}}$ & $\mathbf{I}_{\mathrm{P}}$ & $\mathbf{I}_{\mathrm{K}}$ & $\mathbf{I}_{\mathrm{N}}$ & $\mathbf{I}_{\mathrm{P}}$ & $\mathbf{I}_{\mathbf{K}}$ & DRIS & PSA-DRIS & DRIS & PSA-DRIS \\
\hline -NCid & -19.2 & 10.7 & 8.5 & -217.5 & 232.2 & -14.7 & $\mathrm{~N}$ & $\mathrm{~N}$ & $\mathrm{P}$ & $\mathrm{P}$ \\
\hline -NMoc & -14.0 & $\begin{array}{l}10.1 \\
7.7\end{array}$ & 6.2 & -222.9 & 204.9 & 18.0 & $\mathrm{~N}$ & $\mathrm{~N}$ & $\mathrm{P}$ & $\mathrm{P}$ \\
\hline -PCid & 2.4 & -16.1 & 13.7 & -4.7 & 49.1 & -44.4 & $\mathrm{P}$ & K & K & $\mathrm{P}$ \\
\hline -PMoc & -2.5 & -7.0 & 9.5 & -23.9 & 35.8 & -11.9 & $\mathrm{P}$ & $\mathrm{N}$ & K & $\mathrm{P}$ \\
\hline -KCid & 3.1 & 19.6 & -22.7 & -5.8 & 90.2 & -84.5 & K & K & $\mathrm{P}$ & $\mathrm{P}$ \\
\hline$-\mathrm{KMoc}$ & -4.5 & 29.8 & -25.3 & -106.8 & 159.1 & -52.3 & K & $\mathrm{N}$ & $\mathrm{P}$ & $\mathrm{P}$ \\
\hline control Cid & -10.5 & $\begin{array}{l}29.0 \\
13.6\end{array}$ & -3.1 & -79.7 & 119.6 & -39.9 & $\mathrm{~N}$ & $\mathrm{~N}$ & $\mathrm{P}$ & $\mathrm{P}$ \\
\hline control Moc & -15.0 & 28.6 & -13.6 & -147.2 & 171.5 & -24.3 & $\mathrm{~N}$ & $\mathrm{~N}$ & $\mathrm{P}$ & $\mathrm{P}$ \\
\hline
\end{tabular}

$\mathrm{Moc}=\mathrm{cv}$. Moctezuma; $\mathrm{Cid}=\mathrm{cv}$. $\mathrm{Cid} ;-\mathrm{N}=$ nitrogen deficiency, $-\mathrm{P}=$ phosphorus deficiency, $-\mathrm{K}=$ potassium deficiency.

Table 4. Nutritional factors studied, petiole extract (PE) and leaf(lab) levels, levels of existing standards and established standards (DRIS) in two tomato cultivars. ( ${ }^{\mathrm{x}}$ Scucuglia \& Creste, 2014). Querétaro, UAQ, 2018.

\begin{tabular}{|c|c|c|c|c|c|c|}
\hline \multirow{2}{*}{ Nutrient } & \multicolumn{2}{|l|}{$\mathbf{N}$} & \multicolumn{2}{|c|}{$\mathbf{P}$} & \multicolumn{2}{|l|}{$\mathbf{K}$} \\
\hline & $\mathrm{mg} \mathrm{L}^{-1}$ & $\mathbf{C V}$ & $\mathrm{mg} \mathrm{L}^{-1}$ & $\mathbf{C V}$ & $\mathrm{mg} \mathrm{L}^{-1}$ & $\mathrm{CV}$ \\
\hline PSA Treatments & $550-1100$ & 30 & $190-730$ & 46 & $1500-1800$ & 6 \\
\hline PSA Control & $850-1420$ & 22 & $720-870$ & 8 & $1520-2150$ & 14 \\
\hline & $\mathrm{g} \mathrm{kg}^{-1}$ & $\overline{C V}$ & $\mathrm{~g} \mathrm{~kg}^{-1}$ & $\overline{C V}$ & $\mathrm{~g} \mathrm{~kg}^{-1}$ & $\overline{C V}$ \\
\hline Lab Treatment & $30-39$ & 8 & $2-6$ & 46 & $22-36$ & 21 \\
\hline Lab Control & $40-41$ & 1 & $6-8$ & 12 & $39-42$ & 3 \\
\hline DRIS tomato ${ }^{\mathrm{x}}$ & $29-44$ & & $4-7$ & & $35-51$ & \\
\hline
\end{tabular}

$\mathrm{CV}=$ coefficient of variation.

otherwise insufficient to satisfy the high demand of the new growth zones, as $\mathrm{K}$ is mainly required in the fruits (Marschner, 2011) (Table 1).

Colorimetric analysis of $\mathrm{N}, \mathrm{P}$, and $\mathrm{K}$ in tomato sap yielded values similar to those obtained in the laboratory (foliar analysis), with the values of the two approaches having correlation coefficients greater than $80 \%$ (Table 2 ). Such an approach can allow a producer to rapidly make decisions regarding nutritional imbalances. Colorimetry analysis of $\mathrm{N}, \mathrm{P}$, and $\mathrm{K}$ has been reported to achieve good results, similar to those obtained using standard laboratory methods (Hochmuth et al., 2004). For example, Peña-Fleitas et al. (2015) reported an $\mathrm{R}^{2}$ of 0.88 for the correlation between the sap $\mathrm{NO}^{-3}$ content of greenhouse tomatoes and the $\mathrm{N}$ status in the plant. These observations suggest that colorimetric analysis of PWE is a good method for determining the status of $\mathrm{N}, \mathrm{P}$, and $\mathrm{K}$ in greenhouse tomato. In the present study, very strong relationships were observed between leaf $\mathrm{N}, \mathrm{P}$, and $\mathrm{K}$ contents and the corresponding contents in PE in the deficiency treatments; for example, $\mathrm{R}^{2}$ values of 0.86 to 0.88 for $\mathrm{N}$ were obtained. Among the elements, $\mathrm{P}$ exhibited the strongest relationship $\left(\mathrm{R}^{2}=\right.$ 0.90 to 0.97 ) between leaf and PE. These strong relationships were observed because the nutrients were extracted directly from conductive tissue and not from structural tissue. Compared with leaf analysis, PSA offers a more direct indication of the status of $\mathrm{N}, \mathrm{P}$, and $\mathrm{K}$ in tomato plants since leaf values of $\mathrm{N}, \mathrm{P}$ and $\mathrm{K}$ are less variable than are $\mathrm{PE}$ values in response to element deficiencies in crops (Figure 1).

The DRIS method numerically describes those elements generating nutritional imbalances that can affect crop yield in the form of indices. A negative index indicates that an element is deficient, whereas a positive index indicates its excess; values near zero indicate element balance. Currently, it is difficult to determine how much the excess or deficiency of an element is causing variation in performance. Using the DRIS methodology with foliar analysis, induced deficiencies were confirmed for all treatments. However, in the control treatments of both cultivars, where there were no induced deficiencies, $\mathrm{N}$ deficiency was identified because it is impossible for all elements to be well balanced in the leaf such that the index values are zero. The absorption of nutrients by plants depends on genetic and environmental factors (Wang \& Wu, 2015). This dependence is reflected in the variability of the indices between the control treatments, both using the traditional method (foliar analysis) and the one proposed in this research (PSA-DRIS). For example, for the Cid cultivar, a $\mathrm{N}$ index of -79.74 (PSA-DRIS) was obtained, whereas for Moctezuma, the corresponding value was -147.22. However, the DRIS method analyzes nutrients in pairs, ultimately determining which of them is in imbalance regardless of the cultivar used (Walworth \& Sumner, 1987). In both cultivars, using PSA with the DRIS methodology to determine the nutritional imbalances of $\mathrm{N}, \mathrm{P}$ and $\mathrm{K}$ yielded indices similar to those obtained using the conventional DRIS method (control treatments T7 and T8). However, in those treatments inducing deficiencies, PSA-DRIS 
was only effective relative to DRIS in detecting $\mathrm{N}$ deficiencies in both cultivars and $\mathrm{K}$ deficiency in the Cid cultivar. In contrast, with the DRIS methodology, $\mathrm{P}$ excess was identified in $75 \%$ of the treatments (i.e., of all treatments, including the control treatments), whereas with the PSA-DRIS, P excess was identified in $100 \%$ of the treatments (Table 3).

The results of the foliar analysis in the laboratory are consistent with other studies (Scucuglia \& Creste, 2014); however, the PSA yielded results with little variation, possibly reflecting the developmental stage of the plant. On average, the $\mathrm{N}$ deficiency identified by PSA in the Cid cultivar was $815 \mathrm{mg}$ $\mathrm{L}^{-1}$, whereas that for the Moctezuma cultivar was $600 \mathrm{mg} \mathrm{L}^{-1}$, well below the average value reported as sufficient (1050 $\mathrm{mg} \mathrm{L}^{-1}$ ) in tomato sap (PeñaFleitas et al., 2015). These findings confirm that deficiency was induced by the treatments. Among the elements, $\mathrm{P}$ presented the greatest variation in both the laboratory analysis and the PSA (Table 4). The absolute NPK contents obtained in this study are comparable to the DRIS standards established by Scucuglia \& Creste (2014) for both treatments and controls. However, there were lower $\mathrm{CV}$ values for the results of the control treatments than for those of the deficiency treatments with respect to the reported standards, especially for P (Table 4).

This study confirmed that equipments such as colorimeters that can rapidly and economically measure NPK and other elements in petiole extract can detect nutrient deficiencies in tomato crops more rapidly than can conventional laboratory analyses.

The PSA method successfully detected $62.5 \%$ of the cases of deficiency identified via conventional DRIS analysis, and 100\% agreement in index values of the controls was obtained between DRIS and PSA-DRIS.

More research is necessary to improve the detection of nutrient deficiencies in the PE of tomato using the PSA-DRIS methodology, since as shown in this study, each variety may respond differently during

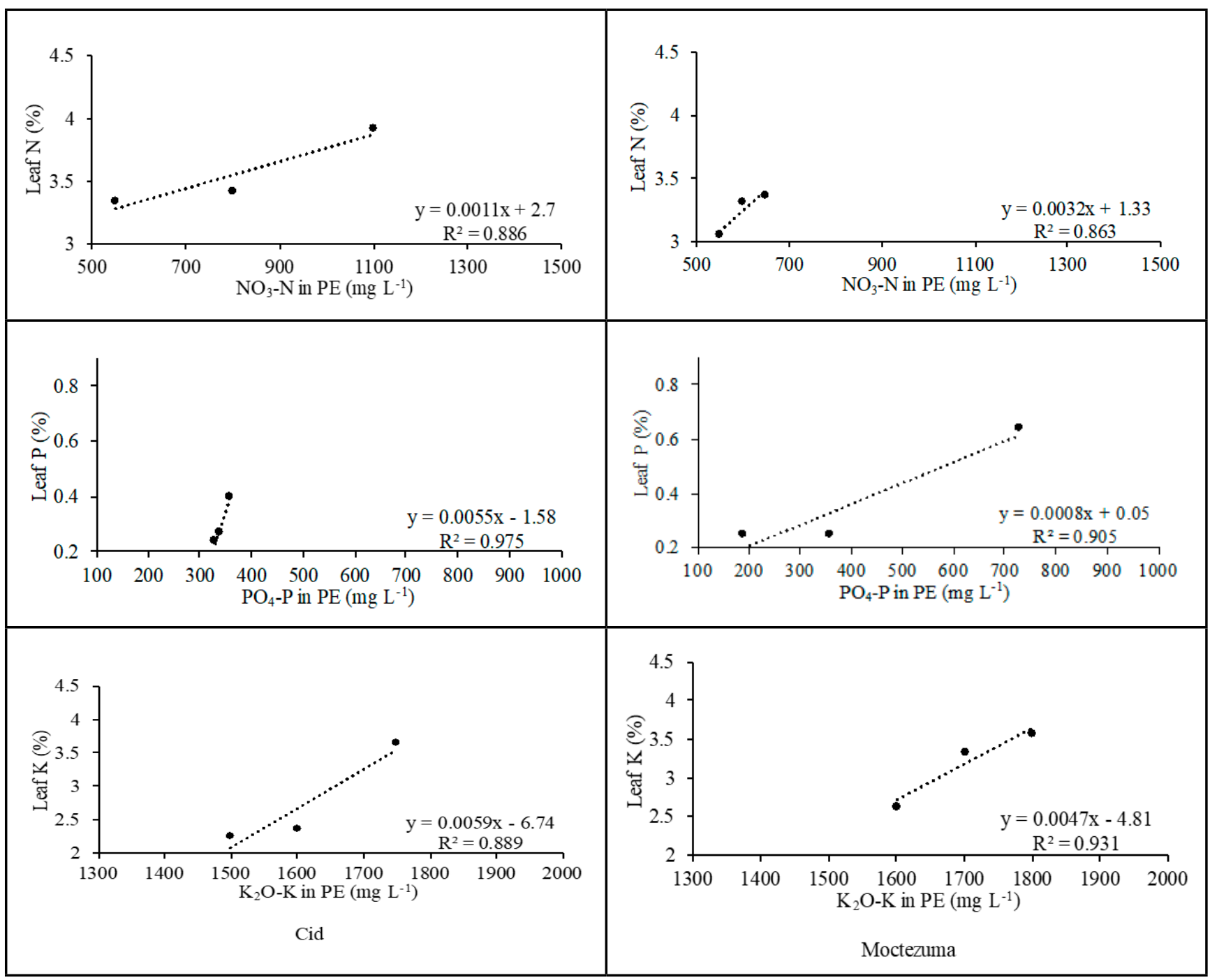

Figure 1. Relationships between leaf and petiole extract (PE) concentrations of nitrogen, phosphorus, and potassium in two tomato cultivars with induced NPK deficiencies. Querétaro, UAQ, 2018. 
nutrient absorption, while conversely, environmental factors can influence such nutrient absorption.

\section{ACKNOWLEDGMENTS}

The authors thank the Universidad Autónoma de Querétaro (Autonomous University of Querétaro) for their support of this research. They also acknowledge FoVin (SUV-DVT-2018-031) and FOFI (FIN-2018-24) for partial support of this research.

\section{REFERENCES}

ARAYA, T; BOHNER, A; WIRÉN, NV. 2015. Extraction of apoplastic wash fluids and leaf petiole exudates from leaves of Arabidopsis thaliana Bio-protocol 5: e1691.

ÁVILA - JUÁREZ，L； RODRÍGUEZGONZÁLEZ, A; RODRÍGUEZ-PIÑA, N; GUEVARA-GONZÁLEZ, RG; TORRESPACHECO, I; OCAMPO-VELÁZQUEZ, RV; MOUSTAPHA, BAH. 2015. Vermicompost leachate as a supplement to increase tomato fruit quality. Journal of Soil Science and Plant Nutrition 15: 46-59.

BEAUFILS, ER. 1973. Diagnosis and Recommendation Integrated System (DRIS). Soil Science Bulletin No. 1, University of Natal, Durban, South Africa. p. 1-132.

BHADURI, D; PAL, S. 2013. Diagnosis and Recommendation Integrated System (DRIS): Concepts and applications on nutritional diagnosis of plant - A review. Journal of Soil and Water Conservation 12: 70-79.

BITYUTSKII, N; YAKKONEN, K.; PETROVA, A.; NADPOROZHSKAYA, M. 2017. Xylem sap mineral analyses as a rapid method for estimation plant-availability of $\mathrm{Fe}, \mathrm{Zn}$ and $\mathrm{Mn}$ in carbonate soils: a case study in cucumber. Journal of Soil Science and Plant Nutrition 17: 279-290.

CADAHÍA, LC. 2008. La savia como índice de fertilización. Cultivos agroenergéticos, hortícolas, frutales y ornamentales. Madrid, España: Mundi-Prensa. p. 25-27.

DEZORDI, LR; AQUINO, LA; AQUINO, RFBA; CLEMENTE, JM; ASSUNÇÃO, NS. 2016. Diagnostic Methods to Assess the Nutritional Status of the Carrot Crop. Revista Brasileira de Ciencia do Solo 40: e0140813.

FARNESELLI, M; TEI, F; SIMONNE, E. 2014. Reliability of petiole sap test for $\mathrm{N}$ nutritional status assessing in processing tomato. Journal of Plant Nutrition 37: 270-278.

GOFFART, J; OLIVIER, M; FRANKINET, M. 2008. Potato crop nitrogen status assessment to improve $\mathrm{N}$ fertilization management and efficiency: Past-Present-Future. Potato Research 51: 355-383.

HOCHMUTH, G; MAYNARD, D; VAVRINA, C; HANLON, E; SIMONNE, E. 2004. Plant tissue analysis and interpretation for vegetable crops in Florida. Publication \#HS964, University of Florida, Florida.

HOPKINS, BG; HORNECK, DA; MACGUIDWIN, AE. 2014. Improving phosphorous use efficiency through potato rhizosphere modification and extensión. American Journal of Potato Research 91: 161-174.

MARSCHNER, H. 2011. Mineral nutrition of higher plants. 3rd ed. London: Academic Press.

OTT-BORRELLI, KA; KOENIG, RT; MILES, CA. 2009. A comparison of rapid potentiometric and colorimetric methods for measuring tissue nitrate concentrations in leafy green vegetables. HortTechnology 19 : 439-444.

PARKS, SE; IRVING, DE; MILHAM, PJ. 2012. A critical evaluation of on-farm rapid tests for measuring nitrate in leafy vegetables. Scientia horticulturae 134: 1-6.

PEÑA-FLEITAS, MT; GALLARDO, M; THOMPSON, RB; FARNESELLI, M;
PADILLA, FM. 2015. Assessing crop N status of fertigated vegetable crops using plant and soil monitoring techniques. Annals of Applied Biology 167: 387-405.

PÍPERAS, GV; CRESTE, JE; ECHER, FR. 2009. Uso do DRIS na avaliação do estado nutricional da cana-de-acúcar. Revista Ceres 56: 818-825.

SCUCUGLIA, CL; CRESTE, JE. 2014. Diagnosis and recommendation integrated system (DRIS) of tomato in greenhouse. Horticultura Brasileira 32: 200-204.

SHUNFENG, G; ZHANLING, Z; LING, P; QIAN, C; YUANMAO, J. 2018. Soil nutrient status and leaf nutrient diagnosis in the main apple producing regions in China. Horticultural Plant Journal 4: 89-93.

SOLTANPOUR, PN; MALAKOUTI, MJ; RONAGHI, A. 1995. Comparison of diagnosis and recommendation integrated system and nutrient sufficient range of corn. Soil Science Society of America Journal 59: 133-139.

STEINER, AA. 1984. The universal nutrient solution. In: PROCEEDINGS 6th INTERNATIONAL CONGRESS ON SOILLES CULTURE. Wageningen, The Netherlands. p. 633-650.

THOMPSON, RB; GALLARDO, M; JOYA, M; SEGOVIA, C; MARTÍNEZ-GAITÁN, C; GRANADOS, MR. 2009. Evaluation of rapid analysis systems for on-farm nitrate analysis in vegetable cropping. Spanish Journal of Agricultural Research 7: 200-211.

TULLY, KL; WEIL, R. 2014. Ion-selective electrode offers accurate, inexpensive method for analyzing soil solution nitrate in remote regions. Communications in Soil Science and Plant Analysis 45: 1974-1980.

WANG, Y; WU, WH. 2015. Genetic approaches for improvement of the crop potassium acquisition and utilization efficiency. Current Opinion in Plant Biology 25: 46-52.

WALWORTH, JL; SUMNER, ME. 1987. The diagnosis and recommendation integrated system (DRIS). In: STEWART, BA (ed). Advances in Soil Science. New York, USA: Springer-Verlag. p. 149-188. 